\title{
Gelişmekte Olan Ülkelerin CDS Primleri Arasındaki Eş-bütünleşme ve Nedensellik İlişkilerinin Araştırılması \\ (Investigating the Cointagration and Causality Relationships Between Developing Countries' CDS Spreads)
}

\author{
Gamze GÖÇMEN YAĞCILAR iD a Zühal ARSLAN iD $b$ \\ a Süleyman Demirel Üniversitesi, İktisadi ve İdari Bilimler Fakültesi, Bankacilık ve Finans Bölümü, Isparta, Türkiye. \\ gamzeyagcilar@sdu.edu.tr \\ b Isparta Uygulamalı Bilimler Üniversitesi, Bankacılık ve Sigortacılık Bölümü, Isparta, Türkiye. zuhalkucukcakal@isparta.edu.tr
}

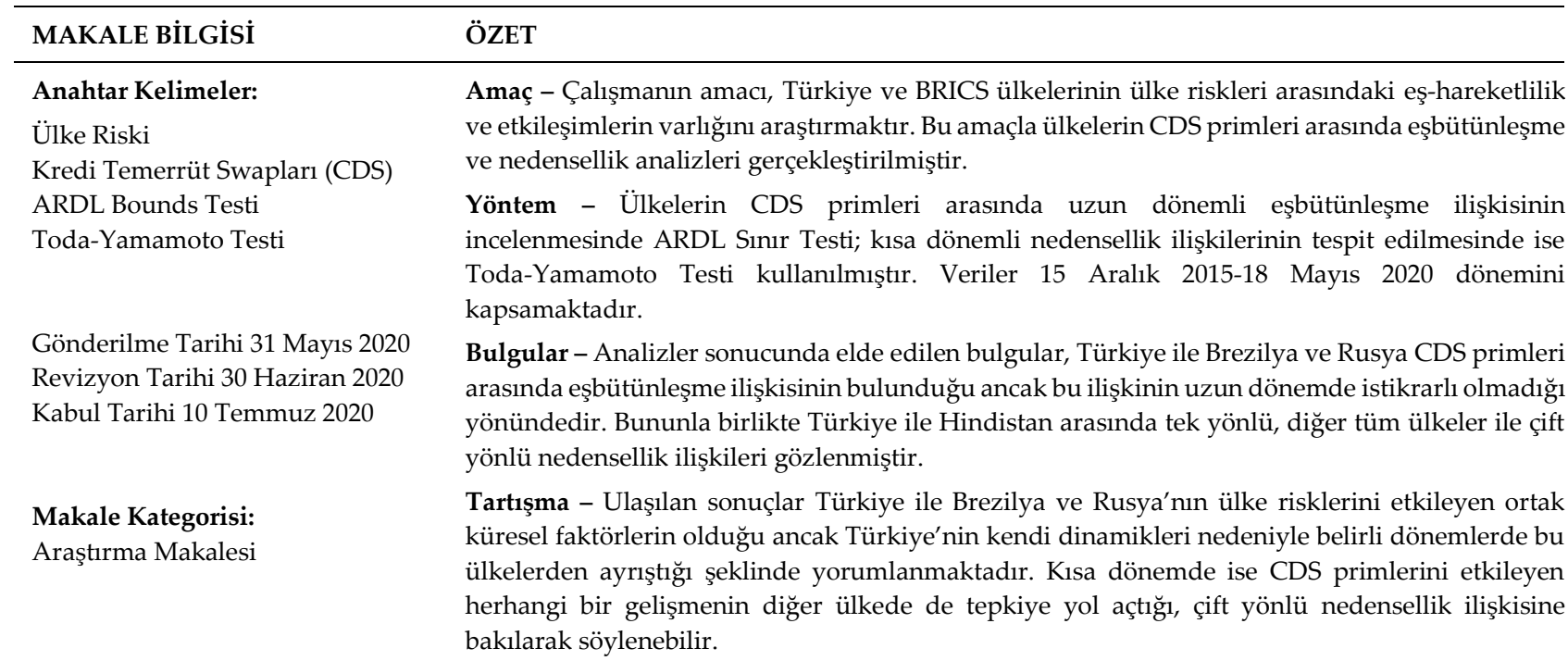

\begin{tabular}{|c|c|}
\hline ARTICLE INFO & ABSTRACT \\
\hline Keywords: & Purpose - The aim of this study is to investigate co-movements and interactions between Turkey \\
\hline Country Risk & and BRICS countries. For this purpose cointegration and causality analysis are performed using \\
\hline Credit Default Swaps (CDS) & CDS spreads of those countries. \\
\hline $\begin{array}{l}\text { ARDL Bounds Test } \\
\text { Toda-Yamamoto Test }\end{array}$ & $\begin{array}{l}\text { Design/methodology/approach - In order to examine the long run cointegrations between CDS } \\
\text { spreads, ARDL Bounds Test is applied. Toda-Yamamoto approach is used to determine the } \\
\text { causality relationships. Data period covers December 15, } 2015 \text { - May 18, } 2020 \text {. }\end{array}$ \\
\hline $\begin{array}{l}\text { Received } 31 \text { May } 2020 \\
\text { Revised } 30 \text { June } 2020 \\
\text { Accepted } 10 \text { July } 2020\end{array}$ & $\begin{array}{l}\text { Findings - Performing ARDL approach, CDS spreads of Turkey are found cointegrated with } \\
\text { Brasil and Russia, however this relationships seem not to be stable for the long run. On the other } \\
\text { hand, Toda-Yamamoto results suggest that causality relationships exist between Turkey and } \\
\text { BRICS countries. }\end{array}$ \\
\hline $\begin{array}{l}\text { Article Classification: } \\
\text { Research Article }\end{array}$ & $\begin{array}{l}\text { Discussion - Cointegrations of CDS spreads of Turkey with Brasil and Russia suggest that ther } \\
\text { are common global factors affecting country risks of those countries, while indosyncratic factors } \\
\text { induce deterioration of long run co-movements. In short run it is possible to state that any factors } \\
\text { affecting the risks in one country causes a reaction in other countries, basing on bi-direcitonal } \\
\text { causalities. }\end{array}$ \\
\hline
\end{tabular}

\section{Önerilen Atıf/ Suggested Citation}

Göçmen Yağcılar, G., Arslan, Z. (2020). Gelişmekte Olan Ülkelerin CDS Primleri Arasındaki Eş-bütünleşme ve Nedensellik İlişkilerinin Araştırılması, İ̧̧letme Araştırmaları Dergisi, 12 (3), 2461-2475. 


\section{GİRİŞ}

Teknolojik gelişmelere bağlı olarak bilgiye erişim olanaklarının artması ve işlem maliyetlerinin azalması, yatırımcıları kendi ülke piyasalarının dışında da işlem yapmaya yöneltmektedir. Küreselleşen ve giderek daha entegre hale gelen uluslararası finansal piyasalarda işlem yapan yatırımcılar böylece risklerini düşürme ve getirilerini arttırma imkanına sahip olabilmektedirler. Ne var ki yatırımclar farklı ülkelerde finansal varlık yatırımı yaptıklarında ülkelerin genel ekonomik, politik ve yasal durumlarındaki gelişmelerden kaynaklanan çeşitli sistematik risklerle karşı karşıya kalmaktadırlar. "Ülke riski" olarak ifade edilebilecek bu riskler, ilgili ülkede ihraç edilen borçlanma araçlarına ilişkin yükümlülüklerin yerine getirilememesi veya hisse senedi yatırımlarının getirilerinin azalması ile sonuçlanabilir. Broto ve Quiros (2015:165) ülke riskinin, kamu kesiminin finansman maliyetlerinin belirlenmesinde önemli bir rolü olduğunu, algılanan riskin artmasının, borçlanma maliyetlerindeki artışla sonuçlanan daha yüksek uzun vadeli yerel faiz oranlarını beraberinde getireceğini öne sürmüşlerdir. Hassan vd. (2003), 10 Orta Asya ve Afrika ülkesi üzerine yaptıkları çalı̧̧mada, ülke riskinin hisse senedi piyasası dalgalanmaları ve getiri tahminlerinde yüksek bir etkisi olduğunu tespit etmişlerdir. Aydın, Hazar ve Çütcü (2016) bazı ülkelerde ülke risk primleri ile borsa endeksleri arasında ilişki bulunabileceğini göstermişlerdir. Yapraklı ve Güngör (2007) ile Tükenmez ve Kutay (2016) ülke riski bileşenleri olan ekonomik, politik ve finansal risk primlerinin borsada işlem gören hisse senetlerinin piyasa değerini; Çam (2010) bu bileşenlerin firma değerini olumsuz yönde etkilediğini ortaya koymuşlardır. Ekinci (2018) ise ülke riskinin Hindistan Rusya ve Çin gibi gelişmekte olan ülkelerde Türkiye'ye kıyasla daha çok etki ettiğini tespit etmiştir. Kısacası ülke riski, yatırımcının beklenen getirisini etkileyebilmektedir.

Ülke riskinin ölçülmesinde ve değerlendirilmesinde farklı göstergeler kullanılmakla birlikte, son yıllarda yaygın olarak dikkate alınan gösterge, Kredi Temerrüt Swap (Credit Default Swap, CDS) primleri olmaktadır. CDS, bir borç ilişkisinden doğan alacağın temerrüt riskinin sigorta edilmesine yarayan bir kredi türevidir. Koruma alan taraf koruma satan tarafa periyodik olarak prim ödemekte, kredinin temerrüde düşmesi halinde ise koruma satan taraf karşı tarafa ödeme yapmaktadır (Erdil, 2008:45). CDS gerek firmaların gerekse devletlerin kullandıkları kredilere dayalı olarak çıkartılabilir ve her bir borç için uygulanacak olan CDS primi, ilgili dayanak kredinin riskine bağlı olarak belirlenir. Kredinin riski arttıkça CDS primi de artar. Dolayısıyla bir ülkenin borçlarına ilişkin yükümlülükleri yerine getirememe ihtimali ne kadar yüksek görünüyorsa CDS primi de o kadar yüksek olmaktadır. Ho (2016:580), CDS primlerine bakılarak iflas olasılığının hesaplanabileceğini ve öngörülebileceğini, dolayısıyla ülke riskinin bir temsilcisi olarak kabul edilebileceğini belirtmiştir. Özellikle 2008 yılında yaşanan küresel mali krizin ardından, piyasanın en güncel durumunu gösteren ve değişen koşullara hızlı bir şekilde adapte olabilen bir gösterge olan CDS'ler, ülke riskinin ölçülmesinde kredi notlarının yerini almıştır (Kılcı, 2017:75). Aydın vd. (2016) CDS primlerini ülke riskinin ölçüsü olarak ele almışlardır. Kocsis ve Monotory (2016) de CDS primlerinin, alternatif ülke riski göstergesi olan tahvil spreadlerine göre üstünlüklerine vurgu yaptıkları çalışmalarında ülke riskinin temsilcisi olarak CDS primlerini kullanmışlardır.

Ülke CDS'lerinin işlem hacmi 2008 Küresel finans krizinin ve takip eden Avrupa borç krizinin ardından artış göstermiştir. Hassan, Isiugo ve Zhang (2016)'ya göre, finansal kriz öncesinde devletlerin kredi riski gelişmiş ülkeler için önemli bir mesele değilken, kriz sonrasında hem gelişmiş hem gelişmekte olan ülkeler için önemi artmıştır. Bunun sonucunda araştırmacıların konuya ilgisinin de son dönemde arttığı görülmektedir. Bir grup araştırmacılar CDS primlerinin belirlenmesinde ülkeye özgü faktörlerin, küresel faktörlerin ya da farklı mekanizmaların hangisinin daha etkili olduğu üzerinde durmaktadırlar ${ }^{1}$. Longstaff vd. (2007:21)'e göre ülkeye özgü faktörlerin küresel faktörlerden daha etkili bulunması, ülke risklerinin yönetilmesinde standart portföy çeşitlendirme yöntemlerinin yararlı olabileceği anlamına gelecektir. Gerçekten de Rajan ve Friedman (1997:55) da uluslararası portföy getirilerinin önemli ölçüde ülke risk primi içerdiğini ileri sürmektedirler.

Diğer bir grup çalışmalarda ise ülke CDS'leri arasındaki eş-hareketlilik ve yayılma etkileri incelenmiştir². Bu çalışmaların temel motivasyonu finansal piyasalardaki risklerin çeşitlendirilme imkânlarının varlık fiyatları arasındaki eş-hareketlilik ile sınırlı olduğu fikridir (Anderson, 2017:243). Longstaff vd. (2007:1)'e göre, ülke kredi riski, ülke borç piyasalarının getiri özelliklerini belirlemekte ve yatırımcıların, bankaların ve diğer finansal kurumların küresel borç portföylerini çeşitlendirilme kabiliyetlerini etkilemektedir. Yazarlar ayrıca

\footnotetext{
${ }^{1}$ Bkz. Bölüm 2.
}

${ }^{2}$ Bkz. Bölüm 2. 
portföy teorisine dayanarak, ülke kredi riskleri arasındaki korelasyonun küresel portföy pozisyonlarının önemli bir belirleyicisi olduğunu ve ülkeler arasındaki sermaye akımlarını etkilediğini ileri sürmektedirler (Longstaff vd., 2007:1). Consiglio vd. (2018:7) portföy yaklaşımdan yola çıkarak dayanak varlıkları arasında negatif korelasyon bulunan CDS'lere yatırım yapıldığında daha yüksek korunma sağlanabileceğini belirtmişlerdir. Wang ve Moore (2012:3) ise yeni sermaye ve yabancı yatırım talebinin yüksek olmasından dolayı gelişmekte olan ülkelerin risk çeşitlendirmesinin ve uluslararası finansal portföylerin faydalarını etkileyebilecek piyasa entegrasyonlarını daha fazla dikkate almaları gerektiğini belirtmişlerdir (Wang and Moore, 2012:3).

Bu bilgiler ışığında çalışmanın odağında, Türkiye'nin ülke CDS primlerinin Brezilya, Rusya, Hindistan, Çin ve Güney Afrika'dan oluşan BRICS ülkelerinin CDS primleri ile arasındaki muhtemel eş-hareketliliğin araştııılması yer almaktadır. Altı ülkenin günlük CDS primleri ARDL Sınır testi ve Toda-Yamamoto (1995) nedensellik testi ile analiz edilmiştir. Türkiye CDS'lerinin Brezilya ve Rusya ile uzun dönemde eş-hareketlilik sergilediği tespit edilmiş olmakla birlikte bu ilişkinin istikrarlı olduğuna dair kanıt sunulamamıştır. Diğer taraftan Hindistan dışındaki tüm ülkelerle çift yönlü, Hindistan ile ise tek yönlü nedensellik ilişkilerinin varlığı daha açık bir şekilde görülmektedir. Elde edilen bulgular incelenen dönemde ülke riskleri arasında geçişkenliğe yol açan mekanizmaların bulunduğu ancak Türkiye'nin kendine özgü dinamikleri nedeniyle CDS'lerinin diğer ülkelerden ayrıştığı şeklinde yorumlanmaktadır. Kısa dönemde ise ülke riskleri arasında yakın etkileşimler olduğu anlaşılmaktadır. Çalışmanın bundan sonraki bölümünde CDS primleri ile ilgili literatür araştırmasına yer verilmiştir. Üçüncü bölümde veri seti ve yöntem tanıtılmış, dördüncü bölümde ise ampirik bulgular sunulmuştur. Sonuç ve değerlendirmeler bölümü ile çalışma tamamlanmaktadır.

\section{LITERATÜR ARAŞTIRMASI}

CDS primleri literatürde oldukça geniş bir perspektifte ele alınmış ve incelenmiştir. Zhu (2004) tahvil primleri ve CDS primlerinin uzun dönemde birlikte hareket ettiğini fakat kısa dönemde bu ilişkinin her zaman söz konusu olmadığını göstermişlerdir. Kim (2004) gelişmekte olan sekiz ülkenin beşinde tahvil primleri ile CDS primleri arasında uzun dönemli ilişki bulmuşlar, Türkiye'nin de aralarında bulunduğu üç ülkede eşbütünleşme ilişkisi tespit edememişlerdir. Hisse senedi fiyatları ile CDS primleri arasında ise yalnızca iki ülkede uzun dönem ilişkisi bulunabilmiştir. Tang ve Yan (2006), tahvil, hisse senedi ve opsiyon piyasalarında CDS piyasasına doğru likidite yayılımı bulunduğu, ayrıca piyasa likiditesinin CDS primleri üzerinde etkili olduğu sonucuna varmışlardır. Chan-Lau ve Fung vd. (2008) hisse senedi piyasası ile yüksek getirili CDS piyasası arasında fiyatlama ve volatilite ile ilgili olarak karşılıklı bilgi geribildirimi olduğu sonucuna ulaşmışlardır. Fontana ve Scheicher (2010) Euro bölgesinde tahvil piyasası ve CDS piyasası arasındaki ilişkinin ülkelere göre farklılık gösterdiğini bulmuşlardır. Palladini ve Portes (2011) 9 AB ülkesini kapsayan analizler neticesinde CDS primleri ve tahvil primleri arasında uzun dönemli ilişkinin varlığını ortaya koymuşlar, kısa dönemde ise CDS primlerinin tahvil primlerine öncülük ettiği sonucuna ulaşmışlardır. Aktuğ (2015) tahvil ve döviz piyasalarının CDS piyasalarındaki fiyat keşfi için baskın bir rol oynadıklarını ortaya koymuştur. Evci (2020) Türkiye' de CDS primleri ile borsa endeksi arasındaki etkileşimi incelemiş̧, değişkenler arasında uzun dönemli ters yönlü bir ilişkinin var olduğunu, kısa dönemde ise CDS primlerinden BIST 100 endeksine doğru bir nedensellik ilişkisinin bulunduğunu ortaya koymuştur.

Ülke riskinin temsilcisi olarak CDS primlerine alternatif olarak kabul edilen bir gösterge, kredi derecelendirme notlarıdır. Literatürde bu ikisi arasındaki ilişkiyi araştıran pek çok çalışma mevcuttur. Cossin (2002), Abid ve Naifar (2006) ile Papaioannou (2011), CDS priminin en önemli değişkeninin kredi notu olduğunu bulmuşlardır. Afonso, Furceri ve Gomes (2011), CDS primleri ile ülke kredi derecelendirme notları arasında negatif yönde ilişki olduğunu ortaya koymuşlardır. Lehnert ve Neske (2006) ile Finnerty, Miller ve Chen (2013) derecelendirme notlarındaki artışların CDS primleri üzerinde önemli bir etkisi olduğunu, Norden ve Weber (2004) ile Ismailescu ve Kazemi (2010) ise CDS primlerinin pozitif kredi olaylarına tepki gösterdiğini ancak negatif kredi olaylarına istatiksel olarak anlamlı bir tepki vermediğini belirtmişlerdir. Aksi yönde bulgular ortaya koyan yazarlardan Micu, Remolona ve Wooldridge (2004) kredi derecelendirme not indiriminin CDS primleri üzerinde oldukça yüksek bir etkisinin olduğunu, Hull, Predescu ve White (2004) pozitif kredi olaylarının negatif kredi olaylarına göre daha az önemli olduğunu tespit etmişlerdir.

CDS piyasası üzerinde makroekonomik değişkenlerin etkisini araştıran çalışmalar da mevcuttur. Buna göre para politikası, enflasyon, reel ekonomik faaliyet, tüketici güveni (Amato, 2005), risksiz faiz oranı (Fabozzi vd. 
2006), kaldıraç ve volatilite (Greatrex, 2009), döviz kurları (Longstaff vd. 2011), GSYİH oranı (Sand, 2012), reel faiz oranı (Eyssell vd. 2013), likidite ve küresel yatırımcı duyarlılığı (Heinz ve Sun 2014), dış borç, uluslararası rezerv ve cari hesap (Ho, 2014) CDS piyasası üzerinde etkili bulunan makroekonomik değişkenlerdir. Ayrıca Bouri vd. (2017) Türkiye'nin de dahil edildiği gelişmekte olan ülkelerin emtia piyasalarından CDS primlerine doğru bir volatilite yayılması olduğunu belirtmişlerdir.

Türkiye'de yapılan çalışmalara bakıldığında ise Özkaplan (2011) ile Ballı ve Yılmaz (2012) CDS primleri ile İMKB-100 endeksi arasında; Karg1 (2014) faiz oranları ile; Hanc1 (2014) hisse senedi getirileri ile; Bozkurt (2015) finansal istikrar ile; Gün vd. (2016), döviz kuru ile; Gök ve Arslan (2019) ise kredi notları ile CDS primi arasında istatistiksel olarak anlamlı ilişkiler bulunduğunu tespit etmişlerdir.

$\mathrm{Bu}$ çalışma ile paralel olarak ülke CDS primleri arasındaki eş-hareketliliği inceleyen çalışmalar farklı ülke/bölge/dönemler için farklı bulgular elde etmişlerdir. Buna göre Hausmann (2000) gelişen piyasalarda ülke riskleri; Longstaff vd. (2007) farklı kıtalardan 26 ülkenin; Shino ve Takahashi (2010) inceledikleri altı ülkenin; Wang ve Moore (2012) gelişmiş ve gelişmekte olan 38 ülkenin; Reyhan ve Gazel (2020) gelişmekte olan ülkelerin CDS primleri arasında yakın ilişkiler bulmuşlardır. Fender, Hayo ve Neuenkirsch (2012) gelişmekte olan ülkelerin CDS primlerinin ülkeye özgü faktörlerden ziyade küresel risk priminden etkilendiğini ifade etmişlerdir. Zinna (2013) CDS primlerinin Latin Amerika ülkelerinde küresel faktörler tarafından, Avrupa ve Asya ülkelerinde ise yerel faktörler tarafından daha iyi açıklandığını bulmuşlardır. Buchholz ve Tonzer (2016) 17 sanayileşmiş ülkenin; Apergis, Lau ve Yarovaya (2016) GIIPSS ülkelerinin; Çepni vd. (2017) gelişmekte olan ülkelerin; Anton vd. (2018) 11 EMU ülkesinin; Arbia vd. (2018) Euro bölgesi ülkelerinin CDS piyasaları arasındaki eş hareketliliğe odaklanmışlardır. Fabozzi, Giacometti ve Tsuchida (2016:2), yapmış oldukları literatür araştırmasına dayanarak, bir ülkenin iflasının o ülkeye özgü faktörlere bağlı olmasına rağmen ülkelerin CDS primlerinin eş-hareketlilik sergilediğini belirtmişlerdir.

Diğer taraftan, Heinz ve Sun (2014) Euro bölgesi ve CESEE ülkelerinin CDS primleri arasında doğrudan bir yayılma etkisi bulunmadığı, bölgelerin kendi içindeki şoklara daha duyarlı oldukları sonucuna varmışlardır. Hassan vd. (2017) Asya, Avrupa ve Latin Amerika'dan 15 ülkenin CDS verilerini analiz etmişler; her bir bölgede güçlü piyasa bağlantıları bulunmakla birlikte Asya piyasalarının diğer bölgelerdeki gelişmelerden daha bağımsız olduğu sonucuna varmışlardır. Consiglio, Lotfi ve Zenios (2018) Avrupa ülkeleri için bir portföy çeşitlendirme modeli geliştirmişler ve CDS primlerine bakarak, çeşitlendirilebilecek önemli miktarda ülkesel risk faktörü bulmuşlardır. Cihangir (2020) ise Türkiye CDS primlerinin volatilitesinin hem küresel hem ulusal faktörlerden etkilendiğini fakat ulusal faktörlerin etkisinin daha önemli olduğunu ortaya koymuştur.

\section{VERI SETI VE YÖNTEM}

Çalışmanın amacı Brezilya, Rusya, Hindistan, Çin ve Güney Afrika'dan oluşan BRICS ülkeleri ile Türkiye'nin CDS primleri arasındaki ilişkinin araştırılmasıdır. Uzun dönemli ilişkinin ortaya konulması amacıyla ARDL yöntemi kullanılmıştır. Ayrıca kısa dönem nedensellik ilişkisinin tespit edilmesi amacıyla Toda-Yamamoto (1995) yöntemi uygulanmıştır. Serilerin bütünleşme derecelerinin belirlenmesinde ADF ve PP birim kök testleri kullanılmıştır.

\subsection{ARDL Model Tanımlaması}

ARDL yöntemi, bağımlı değişkenin, kendisinin ve bağımsız değişkenlerin gecikmeli değerleri ile regresyona tabi tutulduğu bir tekniktir. Çalışmada uzun dönem ilişkileri tahmin etmek için Akel ve Gazel (2014) takip edilerek Pesaran, Shin ve Smith (1999) ile Pesaran vd. (2001) tarafından geliştirilen, 1 No.lu eşitlikte yer alan doğrusal ARDL(m,n) modeli kurulmuştur:

$$
\text { TUR }=\alpha_{0}+\alpha_{1} \text { Trend }+\sum_{i=1}^{m} \alpha_{2 i} T_{U R} R_{t-i}+\sum_{i=0}^{n} \alpha_{3 i} \text { BRICS }_{t-i}+\varepsilon_{i}
$$

Denklem (1)'de verilen model BRICS ülkelerinin her biri için ayrı ayrı çözülmüştür. ARDL modeli çözülerek elde edilen kritik değerler Pesaran vd. (2001)'in üst sınırını geçtiğinde kısa ve uzun dönem katsayılar tahmin edilmektedir (Akel ve Gazel, 2014:31). Uzun dönem katsayıların elde edildiği koşullu hata düzeltme modeli şu şekilde gösterilmektedir: 


$$
\Delta T U R=\alpha_{0}+\alpha_{1} \text { Trend }+\sum_{i=1}^{m} \beta_{1 i} \Delta T U R_{t-i}+\sum_{i=0}^{n} \beta_{2 i} \Delta B R I C S_{t-i}+\delta_{1} T U R_{t-1}+\delta_{2} \text { BRICS }_{t-1}+\varepsilon_{i}
$$

Değişkenler arasındaki eşbütünleşme ilişkisinin değerlendirilmesi için $H_{0}: \delta_{1}=\delta_{2}=0$ hipotezinin reddedilmesi gerekir. Bu hipotezin test edilmesinde Bounds testinden yararlanılmaktadır. Hesaplanan $\mathrm{F}$ istatistiği Pesaran (2001)'in belirttiği kritik değerlerden büyük olduğunda uzun dönemde eşbütünleşme ilişkisinin olmadığı yönündeki Ho hipotezi reddedilmektedir.

Hata düzelme modeli ise Denklem (3)'te görüldüğü şekilde kurulmaktadır:

$$
\Delta T U R=\alpha_{0}+\alpha_{1} \text { Trend }+\sum_{i=1}^{m} \lambda_{1 i} \Delta T U R_{t-i}+\sum_{i=0}^{n} \lambda_{2 i} \Delta B R I C S_{t-i}+\lambda_{3} E_{C C M_{t-i}}+\varepsilon_{i}
$$

Denklem (3) gösterilen $\mathrm{ECM}_{\mathrm{t}-1}$ hata düzeltme terimi olup, uzun dönem ilişkisinin elde edildiği modelin kalıntılarının bir gecikmeli değeridir (Akel ve Gazel, 2014:32). ECM $\mathrm{t}_{-1}$ teriminin negatif ve anlamlı olması, kısa dönemde meydana gelen sapmaların uzun dönemde giderilebildiğini ifade etmektedir.

\subsection{Toda-Yamamoto Model Tanimlaması}

BRICS ülkeleri ve Türkiye' nin CDS primleri arasındaki nedensellik ilişkisinin analizinde Toda ve Yamamoto (1995) tarafından geliştirilen modelden yararlanılmıştır. Modelinin ilk aşaması, bilgi kriterlerinden yararlanılarak VAR modeli için uygun gecikme uzunluğunun (k) belirlenmesidir. Ardından, uygun gecikme uzunluğuna, birim kök testleri ile belirlenen maksimum bütünleşme derecesi $(\mathrm{d} \max )$ eklenmek suretiyle, ülke çiftleri için $\left(\mathrm{k}+\mathrm{d}_{\max }\right)$ boyutunda bir VAR modeli tahmin edilir. Modelin gösterimi Denklem 5 ve Denklem 6 'da yer almaktadır.

$\mathrm{Y}_{\mathrm{t}}=\omega+\sum_{\mathrm{i}=1}^{\mathrm{k}} \alpha_{1, \mathrm{i}} \mathrm{Y}_{\mathrm{t}-\mathrm{i}}+\sum_{\mathrm{j}=\mathrm{k}+1}^{\mathrm{k}+\mathrm{d}_{\max }} \alpha_{2, \mathrm{j}} \mathrm{Y}_{\mathrm{t}-\mathrm{j}}+\sum_{\mathrm{i}=1}^{\mathrm{k}} \beta_{1, \mathrm{i}} \mathrm{X}_{\mathrm{t}-\mathrm{i}}+\sum_{\mathrm{j}=\mathrm{k}+1}^{\mathrm{k}+\mathrm{d}_{\max }} \beta_{2, \mathrm{j}} \mathrm{X}_{\mathrm{t}-\mathrm{j}}+\varepsilon_{1, \mathrm{t}}$

$\mathrm{X}_{\mathrm{t}}=\mu+\sum_{\mathrm{i}=1}^{\mathrm{k}} \gamma_{1, \mathrm{i}} \mathrm{X}_{\mathrm{t}-\mathrm{i}}+\sum_{\mathrm{j}=\mathrm{k}+1}^{\mathrm{k}+\mathrm{d}_{\max }} \gamma_{2, \mathrm{j}} \mathrm{X}_{\mathrm{t}-\mathrm{j}}+\sum_{\mathrm{i}=1}^{\mathrm{k}} \delta_{1, \mathrm{i}} \mathrm{Y}_{\mathrm{t}-\mathrm{i}}+\sum_{\mathrm{j}=\mathrm{k}+1}^{\mathrm{k}+\mathrm{d}_{\max }} \delta_{2, \mathrm{j}} \mathrm{Y}_{\mathrm{t}-\mathrm{j}}+\varepsilon_{2, \mathrm{t}}$

Seriler arasındaki nedensellik ilişkisi, MWALD testi ile araştırılmaktadır. Testin hipotezleri şu şekildedir:

$\mathrm{H}_{0}: \beta_{1,1}=\beta_{1,2}=\cdots=\beta_{1, \mathrm{k}}=0$

$\mathrm{H}_{0}: \delta_{1,1}=\delta_{1,2}=\cdots=\delta_{1, \mathrm{k}}=0$

$\mathrm{H}_{0}$ hipotezlerinin reddedilmesi, $\mathrm{X}$ ve $\mathrm{Y}$ serileri arasında nedensellik ilişkisinin var olduğu anlamına gelmektedir.

\subsection{Veri Seti}

Bu çalışmada Türkiye, Brezilya, Rusya, Hindistan, Çin ve Güney Afrika 5 yıllık Amerikan Doları cinsinden günlük CDS primleri kullanılmıştır. Ele alınan ülkeler farklı kıtalarda konumlanmakla birlikte ortak bazı özellikler taşıdıkları bilinmektedir. Öncelikle tamamı hızlı büyüyen ekonomilerdir. "BRICS" ülkeleri olarak gruplandırılan bu ülkeler ile Türkiye'nin giderek artan yakın ilişkileri olduğu gözlenmektedir. Özellikle Çin ve Rusya Türkiye'nin önemli ticari ortaklarıdır. Diğer taraftan, Rusya dışında bu ülkelerin tamamı (Türkiye dahil) "Yeni Sanayileşen Ülkeler" sınıflandırmasına dahil edilmektedirler. Buna göre sayılan ülkelerin hala tam anlamıyla gelişmiş bir ekonomiye sahip oldukları söylenemezken, diğer gelişmekte olan ülkelere göre daha ileri seviyede oldukları gözlenmektedir. Kuepper (2019), bu piyasalarda uluslararası yatırımcılar için çok sayıda seçenek bulunduğunu ancak yatırımcıların bu fırsatları iyi analiz ederek çeşitlendirilmiş bir portföy oluşturmaları gerektiğini ileri sürmüştür. Bu anlamda bu ülkeler hem coğrafi çeşitlendirme imkânı sunarken, diğer yandan ortak bazı özellikler arz etmektedirler. Dolayısıyla adı geçen ülkelerin ülke riskleri arasındaki etkileşimin araştırılması ile yararlı sonuçlar elde edilebileceği düşünülmektedir. Araştırma 15.12.201518.05.2020 dönemini kapsamaktadır. Veriler paragaranti.com ${ }^{3}$, worldgovernmentbonds.com ${ }^{4}$ ve assetmacro.com ${ }^{5}$ internet siteleri aracıllğıyla derlenmiştir. Verilerine ulaşılamaması nedeniyle Çin için yapılan

\footnotetext{
${ }^{3}$ https://www.paragaranti.com/cds, erişim tarihi: 20.05.2020.

${ }^{4}$ http://www.worldgovernmentbonds.com/cds-historical-data/, erişim tarihi: 20.05.2020.

${ }^{5}$ https://www.assetmacro.com/, erişim tarihi: 20.05.2020.
} 
analizlerin dönemi 01.06.2018-18.05.2020 tarihleri ile sınırlı kalmıştır. Tanımlayıcı İstatistiklere Tablo 1'de yer verilmiştir.

Tablo 1. Tanımlayıcı İstatistikler

\begin{tabular}{|l|l|l|l|l|l|l|}
\hline & TÜRKIYE & BREZILYA & RUSYA & HINDİSTAN & ÇIN & SA \\
\hline Ortalama & 301.0467 & 225.4372 & 160.4560 & 94.3758 & 51.588 & 218.8338 \\
\hline Medyan & 279.3150 & 207.0600 & 145.9835 & 89.1450 & 49.993 & 195.1255 \\
\hline En büyük & 651.9100 & 505.9130 & 395.9880 & 271.4900 & 79.932 & 502.5500 \\
\hline En küçük & 158.6160 & 91.7400 & 54.6100 & 19.2000 & 29.641 & 138.8480 \\
\hline St. Sapma & 103.5687 & 89.4841 & 66.1094 & 29.5371 & 11.860 & 64.1058 \\
\hline Çarpıklık & 0.9744 & 1.0047 & 0.9787 & 2.5223 & 0.1919 & 1.5370 \\
\hline Basıklık & 3.7281 & 3.8315 & 3.8209 & 11.4623 & 2.0061 & 4.9900 \\
\hline Jarque-Bera (JB) & 196.2103 & 214.3861 & 204.2586 & 4399.9450 & 24.217 & 607.9266 \\
\hline Olasılık (JB) & 0.0000 & 0.0000 & 0.0000 & 0.0000 & 0.0000 & 0.0000 \\
\hline Gözlem Say. & 1088 & 1088 & 1088 & 1088 & 512 & 1088 \\
\hline
\end{tabular}

6 ülkeye ait 1088 gözleme dayalı veri seti incelendiğinde, BRICS ülkeleri ile karşılaştırıldığında Türkiye'nin CDS primlerinin diğer ülkelerin tamamından daha yüksek olduğu görülmektedir. Türkiye'yi Brazilya ve G. Afrika izlemektedir. En büyük değerlere bakıldığında da Türkiye için oldukça yüksek değer dikkat çekmektedir. Ayrıca Türkiye'nin CDS primlerinin standart sapması da diğer ülkelere kıyasla oldukça yüksek bulunmuştur. Çin'in primlerinin ise diğer ülkelerin oldukça altında olduğu ve standart sapmasının da düşük olduğu dikkat çekmektedir. Çin'i Hindistan izlemektedir. Çarpıklık, basıklık ve JB istatistiği de CDS primlerinin normal dağılım sergilemediğine işaret etmektedir.

Ülkelerin CDS primlerinin zaman içerisindeki hareketlerini gösteren grafik Şekil 1'de yer almaktadır.

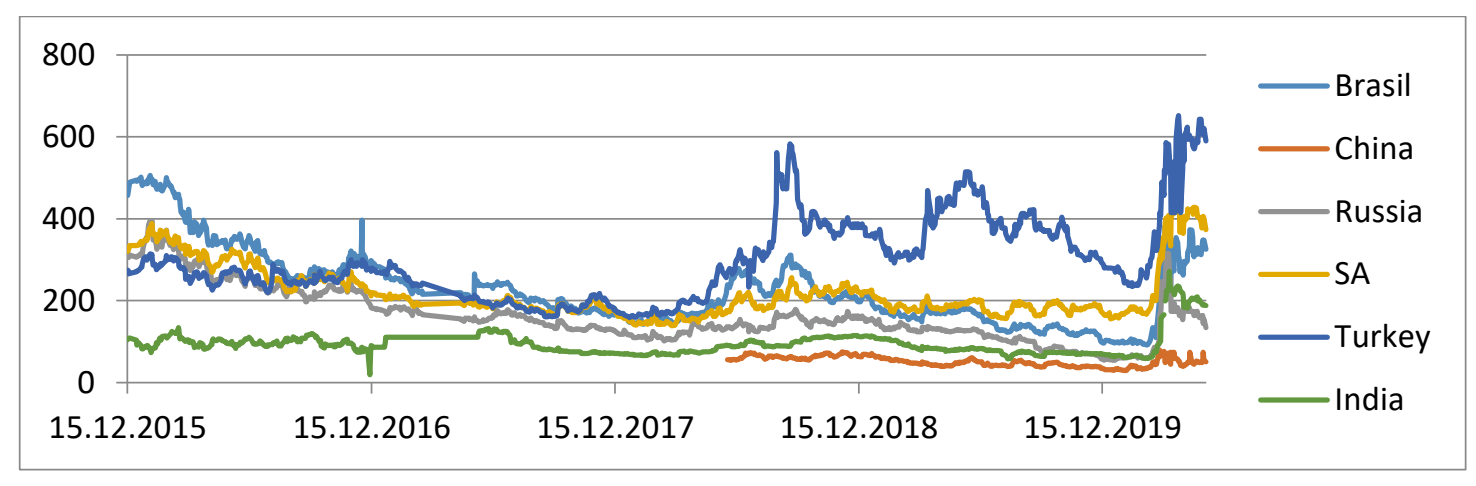

Şekil 1. BRICS ülkeleri ve Türkiye'nin CDS primlerinin değişimi

Şekil 1'de sunulan grafikte görüldüğü gibi Türkiye CDS primlerinin incelenen dönemin başından itibaren Brezilya, Rusya ve Güney Afrika ile birlikte hareket ettiği, Hindistan'ın ise gruptan farklı bir seyir izlediği gözlenmektedir. 2018 yılına kadar, sayılan dört ülkede düşüş eğilimi oluşmuş, 2018 sonuna kadar süren yükseliş, 2019 sonuna doğru tekrar hafif bir düşüş eğilimi göstermiştir. 2018 yılına kadar Brezilya, Rusya ve Güney Afrika ile benzer bir trend sergileyen Türkiye'nin bu yıldan sonra diğer ülkelerden negatif yönde ayrıştığı anlaşılmaktadır. Bu ayrışma üzerinde Türkiye'nin ülke riskinin, 2018 yılının ortalarında yaşanan döviz şokunun ve 2019 yılında ABD ile yaşanan S 400 gerginliğinin etkili olduğu düşünülmektedir. Çin'e ait verilerin eksik olması nedeniyle bu ülke ile ilgili yorumlarımız eksik kalmaktadır. Ancak dikkat çeken bir diğer nokta, 2019'un bitimini takiben (Çin'de daha sınırlı olmakla birlikte) tüm ülkelerde CDS primlerinde gözlenen keskin yükseliştir. Bu yükseliş üzerinde 2020 yılı içerisinde artış gösteren Covid-19 pandemisi nedeniyle ulusal ve uluslararası ticari faaliyetlerin durma noktasına gelmesinin ve tüm ülkelerde beklenen ekonomik daralmanın da etkili olduğu tahmin edilmektedir. 


\section{BULGULAR}

\subsection{Birim Kök Testi Sonuçları}

Yöntem, tamamı I(0), tamamı I(1) ve hem I(0) hem I(1) regresörlerin analizine imkân vermekle birlikte maksimum bütünleşme derecesinin I(1) olmasını gerektirmektedir. Dolayısıyla analize başlamadan önce birim kök testleri yapılmak suretiyle maksimum bütünleşme derecesinin I(1) olduğunu göstermek gerekmektedir. Bu amaçla ADF ve PP birim kök testlerinden yararlanılmıştır. Test sonuçları Tablo 2'de görülmektedir.

Tablo 2. Birim Kök Testleri

\begin{tabular}{lllll}
\hline & & ADF & PP \\
\hline Türkiye (düzey) & Sabit & Sabit \& Trend & Sabit & Sabit \&Trend \\
Türkiye (1. fark) & -0.8335 & -1.9208 & -1.2548 & -2.318 \\
Brezilya (düzey) & $-11.774^{* * *}$ & $-11.844^{* * *}$ & $-37.959^{* * *}$ & $-38.035^{* * *}$ \\
Brezilya (1. fark) & $-2.7876^{*}$ & -1.3604 & -2.5096 & -1.677 \\
Rusya (düzey) & $-16.828^{* * *}$ & $-17.077^{* * *}$ & $-36.448^{* * *}$ & $-36.878^{* * *}$ \\
Rusya (1. fark) & $-2.718^{* *}$ & -3.015 & -2.465 & -2.739 \\
Hindistan (düzey) & $-10.926^{* * *}$ & $-10.978^{* * *}$ & $-31.902^{* * *}$ & $-31.926^{* * *}$ \\
Hindistan (1. fark) & -2.048 & -2.065 & -2.351 & -2.366 \\
Çin (düzey) & $-38.247^{* * *}$ & $-38.257^{* * *}$ & $-37.900^{* * *}$ & $-37.910^{* * *}$ \\
Çin (1. fark) & -2.277 & -2.873 & $-2.973^{* *}$ & $-4.079^{* * *}$ \\
G. Afrika (düzey) & $-9.372^{* * *}$ & $-9.365^{* * *}$ & $-33.561^{* * *}$ & $-33.529^{* * *}$ \\
G. Afrika (1. fark) & -2.356 & -1.904 & -1.767 & -1.263 \\
\hline & $-7.293^{* * *}$ & $-16.876^{* * *}$ & -31.573 & $-31.605^{* * *}$ \\
Anlamlllk & Sabitli Model için & kritik değerler & Sabitli ve Trendli Model için kritik değerler \\
$1 \%$ & ADF & PP & ADF & PP \\
$5 \%$ & -3.4354 & -3.434 & -3.9654 & -3.9635 \\
$10 \%$ & -2.8637 & -2.8631 & -3.4134 & -3.4125 \\
\hline & -2.5679 & -2.5676 & -3.1288 & -3.1282 \\
\hline
\end{tabular}

NOT: ${ }^{*}{ }^{* *}$ ve ${ }^{* * *}$ sembolleri sirasılyla $10 \%, 5 \%$ ve $1 \%$ anlamlılık seviyelerini ifade etmektedir.

Tablo 2' de tüm ülkeler için CDS primlerinin düzey ve fark serileri için ADF ve PP birim kök testlerinden elde edilen istatistik değerleri yer almaktadır. Tüm seriler için düzey değerlerin birim kök içerdiği, ancak 1 . Farklarının alınması durumunda durağan hale geldikleri görülmektedir. İstisnai olarak Çin PP testi sonuçlarına göre düzeyde durağan bulunmuş, ancak ADF testi ile bu sonuç doğrulanmamıştır. Bu sonuçlara göre tüm değişkenler için maksimum bütünleşme derecesinin I(1) olduğu tespit edilmiş ve veri setinin ARDL modeli için uygun olduğuna karar verilmiştir.

\subsection{Uzun Dönemli İlişkilere Ait Bulgular}

Türkiye'nin CDS primlerinin diğer beşülke ile olan uzun dönemli ilişkisinin tespit edilmesi amacıyla, her birinde Türkiye'nin bağımlı değişken olduğu beş model kurulmuştur. Analizlerin bulguları Tablo 3'te gösterilmiştir. 
G. Göçmen Yağcılar - Z. Arslan 12/3 (2020) 2461-2475

Tablo 3. ARDL Koşullu Hata Düzeltme ve Bounds Testi Sonuçları

\begin{tabular}{|c|c|c|c|c|c|c|c|c|c|}
\hline \multicolumn{10}{|c|}{ Bağımlı Değişken: TUR } \\
\hline \multicolumn{2}{|c|}{$\begin{array}{l}\text { Bağımsız Değ. } \\
\text { BRA } \\
\text { ARDL }(2,4)\end{array}$} & \multicolumn{2}{|c|}{$\begin{array}{l}\text { Bağımsız Değ. } \\
\text { RUS } \\
\text { ARDL(2,4) }\end{array}$} & \multicolumn{2}{|c|}{$\begin{array}{l}\text { Bağımsız Değ. } \\
\text { IND } \\
\text { ARDL }(2,4)\end{array}$} & \multicolumn{2}{|c|}{$\begin{array}{l}\text { Bağımsız Değ. } \\
\text { CHN } \\
\text { ARDL }(2,4)\end{array}$} & \multicolumn{2}{|c|}{$\begin{array}{l}\text { Bağımsız Değ. } \\
\text { SA } \\
\text { ARDL }(2,4)\end{array}$} \\
\hline Değişken & Katsayı & $\mathrm{D}$ & K & $\mathrm{D}$ & $\mathrm{K}$ & $\mathrm{D}$ & $\mathrm{K}$ & $\mathrm{D}$ & $\mathrm{K}$ \\
\hline $\bar{C}$ & $\begin{array}{l}-4.235 \\
(2.664)\end{array}$ & C C & $\begin{array}{l}-8.399^{* * * *} \\
(2.986)\end{array}$ & $\bar{C}$ & $\begin{array}{l}1.269 \\
(1.811)\end{array}$ & $\overline{\mathrm{C}}$ & $\begin{array}{l}-7.097 \\
(7.226)\end{array}$ & $\bar{C}$ & $\begin{array}{l}-0.899 \\
(1.973)\end{array}$ \\
\hline Trend & $\begin{array}{l}0.012 * * * \\
(0.004)\end{array}$ & Trend & $\begin{array}{l}0.016^{* * *} \\
(0.004)\end{array}$ & Trend & $\begin{array}{l}0.004^{* *} \\
(0.002)\end{array}$ & Trend & $\begin{array}{l}0.020^{* *} \\
(0.009)\end{array}$ & Trend & $\begin{array}{l}0.005^{* *} \\
(0.002)\end{array}$ \\
\hline TURt-1 & $\begin{array}{l}-0.032^{* * *} \\
(0.008)\end{array}$ & TUR $_{\mathrm{t}-1}$ & $\begin{array}{l}-0.030^{* * *} \\
(0.008)\end{array}$ & TUR $_{\mathrm{t}-1}$ & $\begin{array}{l}-0.019^{* * *} \\
(0.007)\end{array}$ & $\mathrm{TUR}_{\mathrm{t}-1}$ & $\begin{array}{l}-0.033^{* * *} \\
(0.012)\end{array}$ & $\mathrm{TUR}_{\mathrm{t}-1}$ & $\begin{array}{l}-0.02^{* * *} \\
(0.007)\end{array}$ \\
\hline BRA $_{t-1}$ & $\begin{array}{l}0.034^{* * *} \\
(0.011)\end{array}$ & RUS $_{\mathrm{t}-1}$ & $\begin{array}{l}0.058^{* * * *} \\
(0.016)\end{array}$ & $\mathrm{IND}_{\mathrm{t}-1}$ & $\begin{array}{l}0.024 \\
(0.019)\end{array}$ & $\mathrm{CH}_{\mathrm{t}-1}$ & $\begin{array}{l}0.2934^{* *} \\
(0.119)\end{array}$ & $\mathrm{SA}_{\mathrm{t}-1}$ & $\begin{array}{l}0.023^{* *} \\
(0.010)\end{array}$ \\
\hline$\Delta \mathrm{TUR}_{\mathrm{t}-1}$ & $\begin{array}{l}-0.204^{* * *} \\
(0.029)\end{array}$ & $\Delta \mathrm{TUR}_{\mathrm{t}-1}$ & $\begin{array}{l}-0.132^{* * * *} \\
(0.030)\end{array}$ & $\Delta \mathrm{TUR}_{\mathrm{t}-1}$ & $\begin{array}{l}-0.115^{* * *} \\
(0.030)\end{array}$ & $\Delta \mathrm{TUR}_{\mathrm{t}-1}$ & $\begin{array}{l}-0.121^{* * *} \\
(0.044)\end{array}$ & $\Delta \mathrm{TUR}_{\mathrm{t}-1}$ & $\begin{array}{l}-0.23^{* * * *} \\
(0.030)\end{array}$ \\
\hline$\triangle \mathrm{BRA}$ & $\begin{array}{l}0.128^{* * *} \\
(0.045)\end{array}$ & $\triangle$ RUS & $\begin{array}{l}1.011^{* * * *} \\
(0.062)\end{array}$ & $\triangle \mathrm{IND}$ & $\begin{array}{l}0.311^{* * *} \\
(0.10)\end{array}$ & $\Delta \mathrm{CH}_{\mathrm{t}}$ & $\begin{array}{l}0.442^{*} \\
(0.253)\end{array}$ & $\triangle \mathrm{SA}$ & $\begin{array}{l}0.147^{* * *} \\
(0.056)\end{array}$ \\
\hline$\triangle \mathrm{BRA}_{\mathrm{t}-1}$ & $\begin{array}{l}0.407^{* * *} \\
(0.046)\end{array}$ & $\Delta \mathrm{RUS}_{\mathrm{t}-1}$ & $\begin{array}{l}0.014 \\
(0.069)\end{array}$ & $\Delta \mathrm{IND}_{\mathrm{t}-1}$ & $\begin{array}{l}0.275^{* * *} \\
(0.102)\end{array}$ & $\Delta \mathrm{CH}_{\mathrm{t}-1}$ & $\begin{array}{l}0.966^{* * *} \\
(0.279)\end{array}$ & $\Delta \mathrm{SA}_{\mathrm{t}-1}$ & $\begin{array}{l}0.740^{* * *} \\
(0.057)\end{array}$ \\
\hline$\triangle \mathrm{BRA}_{\mathrm{t}-2}$ & $\begin{array}{l}0.311^{* * *} \\
(0.047)\end{array}$ & $\Delta \mathrm{RUS}_{\mathrm{t}-2}$ & $\begin{array}{l}0.256^{* * *} \\
(0.062)\end{array}$ & $\Delta \mathrm{IND}_{\mathrm{t}-2}$ & $\begin{array}{l}0.022^{* * *} \\
(0.101)\end{array}$ & $\Delta \mathrm{CH}_{\mathrm{t}-2}$ & $\begin{array}{l}-0.193 \\
(0.284)\end{array}$ & $\Delta \mathrm{SAt}_{\mathrm{t}-2}$ & $\begin{array}{l}0.363^{* * *} \\
(0.060)\end{array}$ \\
\hline$\triangle \mathrm{BRA}_{\mathrm{t}-3}$ & $\begin{array}{l}0.260^{* * *} \\
(0.045)\end{array}$ & $\Delta \mathrm{RUS}_{\mathrm{t}-3}$ & $\begin{array}{l}-0.201^{* * *} \\
(0.063)\end{array}$ & $\Delta \mathrm{IND}_{\mathrm{t}-3}$ & $\begin{array}{l}-0.392^{* * *} \\
(0.107)\end{array}$ & $\Delta \mathrm{CH}_{\mathrm{t}-3}$ & $\begin{array}{l}0.808^{* * * *} \\
(0.270)\end{array}$ & $\Delta \mathrm{SA}_{\mathrm{t}-3}$ & $\begin{array}{l}0.194^{* * * *} \\
(0.056)\end{array}$ \\
\hline \multicolumn{10}{|c|}{ UZUN DÖNEM KATSAYILAR } \\
\hline L_BRA & $\begin{array}{l}1.070^{* * * *} \\
(0.294) \\
\end{array}$ & L_RUS & $\begin{array}{l}1.947^{* * *} \\
(0.512)\end{array}$ & L_IND & $\begin{array}{l}1.289 \\
(1.957) \\
\end{array}$ & L_CH & $\begin{array}{l}9.029 \\
(5.580) \\
\end{array}$ & L_SA & $\begin{array}{l}1.065^{*} \\
(0.644))\end{array}$ \\
\hline \multicolumn{10}{|c|}{ HATA DÜZELTME KATSAYILARI } \\
\hline $\begin{array}{l}\text { CointEq } \\
(-1)\end{array}$ & $\begin{array}{l}-0.032^{* * *} \\
(0.008) \\
\end{array}$ & & $\begin{array}{l}-0.030^{* * *} \\
(0.007) \\
\end{array}$ & & $\begin{array}{l}-0.019^{* * *} \\
(0.007) \\
\end{array}$ & & $\begin{array}{l}-0.033^{* * *} \\
(0.011) \\
\end{array}$ & & $\begin{array}{l}-0.02^{* * *} \\
(0.007) \\
\end{array}$ \\
\hline $\begin{array}{l}\text { F-stat. } \\
\text { (Bounds) }\end{array}$ & $7.461^{* *}$ & F-stat. & $8.059^{* *}$ & F-stat. & 4.279 & F-stat. & 4.644 & F-stat. & 4.524 \\
\hline t-stat. & $-3.85^{* *}$ & t-stat. & $-3.820^{* *}$ & t-stat. & -2.911 & t-stat. & -2.722 & t-stat. & -2.993 \\
\hline $\mathrm{ARCH}(2)$ & 0.000 & $\mathrm{ARCH}(2)$ & 0.000 & $\mathrm{ARCH}(2$ & 0.000 & $\mathrm{ARCH}(2)$ & 0.000 & $\mathrm{ARCH}(2$ & 0.000 \\
\hline $\mathrm{BG}(2)$ & 0.958 & $\mathrm{BG}(2)$ & 0.059 & $\mathrm{BG}(2)$ & 0.277 & $\mathrm{BG}(2)$ & 0.612 & $\mathrm{BG}(2)$ & 0.152 \\
\hline \multirow{5}{*}{$\begin{array}{l}\text { F İstatistiği } \\
\text { Kritik } \\
\text { Değerleri } \\
\text { Pesaran } \\
(2001)\end{array}$} & Sig. & $\mathrm{I}(0)$ & $\mathrm{I}(1)$ & & \multirow{5}{*}{$\begin{array}{l}\mathrm{T} \\
\text { İstatistiği } \\
\text { Kritik } \\
\text { Değerleri }\end{array}$} & Sig. & $\mathrm{I}(0)$ & $\mathrm{I}(1)$ & \\
\hline & $10 \%$ & 5.59 & 6.26 & & & $10 \%$ & -3.13 & -3.4 & \\
\hline & $5 \%$ & 6.56 & 7.3 & & & $5 \%$ & -3.41 & -3.69 & \\
\hline & $2.50 \%$ & 7.46 & 8.27 & & & $2.50 \%$ & -3.65 & -3.96 & \\
\hline & $1 \%$ & 8.74 & 9.63 & & & $1 \%$ & -3.96 & -4.26 & \\
\hline
\end{tabular}

NOT: Parantez içindeki değerler standart hatalardır. * ${ }^{* *}$ ve *** sembolleri sırasıyla $\% 10, \% 5$ ve $\% 1$ anlamlılık seviyelerinde anlamlı olan istatistik değerlerini ifade etmektedir.

Ülkelerin CDS primleri arasındaki uzun dönemli ilişkinin incelendiği tüm modeller için tanı testlerinde seri korelasyon problemi (BG-LM testi) bulunmamakla birlikte değişen varyans sorunu (ARCH testi) görülmüş, bu nedenle modellerin çözümünde Newey-West tahmincisi kullanılmıştır. Tanı testlerinin sonuçları ve Akaike Bilgi Kriteri (AIC) ile belirlenen gecikme uzunluklar1 ${ }^{6}$, Tablo 3'te yer almaktadır.

Bulgular incelendiğinde Brezilya ve Rusya için kurulan modellerde Bounds testinden elde edilen $\mathrm{F}$ istatistiğinin değerlerinin, Pesaran vd. (2001) tarafından belirlenen I(1) kritik değerlerinden yüksek olduğu görülmektedir (\%5 anlamlılık seviyesinde). Bu sonuçlar, hiçbir düzeyde ilişki olmadığı yönündeki $\mathrm{H} 0$ hipotezinin reddedilmesini sağlamaktadır. Bu modellerden elde edilen uzun dönem katsayıların tamamı \%1 anlamlılık seviyesinde anlamlıdır ve katsayıların pozitif olduğu görülmektedir. Ayrıca eşbütünleşme eşitliğinden elde edilen katsayıların da negatif ve anlamlı olduğu bulunmuştur. Bu bulgu da kısa dönemde ortaya çıkan şokların etkisinin uzun dönemde ortadan kalktığına işaret etmektedir. Tüm bu sonuçlar,

${ }^{6}$ Maksimum 4 gecikme alınmıştır. 
Türkiye'nin CDS primlerinin Brezilya ve Rusya'nın CDS primleri ile uzun dönemli ilişki içerisinde olduğuna işaret etmektedir.

Hindistan, Çin ve G. Afrika için kurulan modellerde, eşbütünleşme katsayılarının negatif ve anlamlı olduğu bulunmakla birlikte Bounds testi sonuçları uzun dönemli ilişkinin varlığına dair bir kanıt sunmamıştır. Uzun dönem katsayıları da Hindistan ve Çin için anlamlı bulunmamış, G. Afrika için \%10 anlamlılık düzeyinde anlamlı bulunmuştur. Hindistan ve Çin için elde edilen sonuçlar, Hassan vd. (2017)'nin Asya ekonomilerinin kendi aralarında müşterek hareket ettiği fakat diğer bölgelerdeki şoklara daha az tepki verdiği yönündeki bulgularını destekler niteliktedir.

Brezilya ve Rusya ile Türkiye'nin CDS primleri arasında tespit edilen uzun dönemli ilişkinin istikrarının araştırılması amacıyla hataların ve hata karelerin kümülatif toplamlarına ait CUSUM ve CUSUM-Sq grafikleri oluşturulmuştur (Şekil 2). CUSUM grafiklerinde \%5 anlamlılık seviyesinde kritik sınırların aşılmadığı ancak CUSUM-Sq grafiklerinde kritik sınırların dışında kalındığı görülmektedir. Bu bulgu, Türkiye'nin ülke riskinin, diğer ülkelerle uzun dönemde eş-hareketlilik sergilediği yönündeki Bounds testi sonuçlarının geçerliliğini şüpheye düşürmektedir. CUSUM-Sq grafikleri ilişkinin, ele alınan dönemin başından itibaren istikrarsız olduğunu ortaya koymaktadır. Farklı modellerden elde edilen grafiklerin benzer yapıda olması, eşhareketlilikten sapmalara neden olan gelişmelerin Türkiye kaynaklı olduğunu düşündürmektedir. Buna göre Türkiye'nin ülke riskini etkileyen faktörlerin diğer ülkelere sirayet etmediği, ayrıca Türkiye' nin riski üzerinde kendi ekonomik temellerinin uluslararası faktörlerden daha etkili olduğu tahmin edilmektedir. Ayrıca türev ürünlere spekülatif amaçlarla yapılan yatırımların yaygınlığının da Türkiye için ortaya konulan ayrışma üzerinde etkili olduğu düşünülmektedir.

Elde edilen sonuçlar Türkiye'nin CDS primlerinin iki ülke ile kararsız bir uzun dönem ilişkisinde olduğunu, üç ülke ile ise bir eşbütünleşmenin bulunmadığını göstermektedir. Bu bulguların şaşırtıcı ya da çelişkili olduğu söylenemez. Çünkü önceki çalışmaların sonuçlarına bakıldığında CDS hareketlerinin ülkeden ülkeye, bölgeden bölgeye ya da ele alınan döneme göre farklılaşabildiği görülmektedir. Örneğin Fender Hayo ve Neuenkirsch (2012), makroeknomik faktörlerin yalnızca küresel kriz öncesinde CDS primleri üzerinde etkili olduğunu göstermişlerdir. Longstaff vd. (2007), Shino ve Takahashi (2010), Wang ve Moore (2012), Buchholz ve Tonzer (2016), Çepni vd. (2017) CDS primlerinin, küresel faktörler ve yayılma etkisi nedeniyle birbirleriyle yüksek korelasyona sahip ve eş-hareketlilik eğilimde olduğuna dair kanıtlar sunmaktadırlar. Varlık ve Varlık (2017) Türkiye üzerine yaptıkları araştırmada küresel faktörlerin CDS volatilitesi üzerinde anlamlı etkilere sahip olduğunu ortaya koymuşlardır. Pan ve Singleton (2008)'in Meksika, Türkiye ve Kore'yi ele aldıkları çalışmalarında üç ülkenin CDS primlerine etki eden risk faktörlerinin ülkeler arasında birlikte değiştiğini ortaya konulmuş; CDS primlerinin işlem maliyetleri, yatırımcıların risk iştahı ve ABD reel ekonomisindeki gelişmelerden diğer bölgelere doğru gerçekleşen yayılma etkisinden kaynaklandığını ifade edilmiştir. Ayrıca bu üç ülkenin, fakat özellikle Türkiye'nin yerel ve bölgesel risk faktörlerinden etkilendiğine de vurgu yapılmıştır. Diğer taraftan Caceres vd. (2010) küresel krizin ilk yıllarında küresel risk iştahının ülke CDS primlerinin en önemli belirleyicisi olduğunu ancak sonraki dönemlerde ülkeye özgü faktörlerin rolünün öne çıktığını bulmuşlardır. Heinz ve Sun (2014) Euro bölgesi ile CESEE ülkelerinin CDS piyasalarını incelemişler ve bölgeler arasında yayılma etkisinin sınırlı olduğu sonucuna varmışlardır. Stolbov (2014) bazı AB ülkeleri ile BRICS ülkeleri arasında CDS primleri ile ilgili bir nedensellik ilişkisi tespit edememiş ve CDS piyasalarındaki ayrışmaya vurgu yapmıştır. Consiglio, Lotfi ve Zenios (2018) yatırımcılar için çeşitlendirme imkânı sağlayacak şekilde ülkeye özgü faktörlerin CDS primleri üzerindeki etkisinin önemine işaret etmişlerdir. Benzer bir bulgu Hassan vd. (2017) tarafından elde edilmiş, çalışmada Asya' daki gelişmekte olan piyasalardan farklı olarak Avrupa ve Latin Amerika gelişmekte olan piyasaları arasında korelasyonun düşük olduğu ve yüksek çeşitlendirmeden fayda sağlanabileceği öne sürülmüştür. Asgharian, Liu ve Larsson (2018) Euro bölgesinde CDS primleri arasındaki eş hareketliliğin küresel kriz sonrasında azaldığını, bu duruma yol açan faktörün ise ülkelerin borç ödeme gücündeki farklılıklar olduğunu göstermişlerdir. Milobedzki ve Nowak (2019), CDS primlerinin daha çok ülkeye özgü dinamiklerle açıklandığı sonucuna varılmıştır. Cihangir (2020)'in Türkiye için yerel faktörlerin etkisinin küresel faktörlerden daha güçlü olduğu vurgusu, bu çalışmanın bulgularını desteklemektedir. Dolayısıyla ele alınan dönemde Türkiye'de yaşanan ekonomik ve politik gelişmelerin ortaya çıkan ayrışmada rol oynadığı anlaşılmaktadır. 
G. Göçmen Yağcılar - Z. Arslan 12/3 (2020) 2461-2475

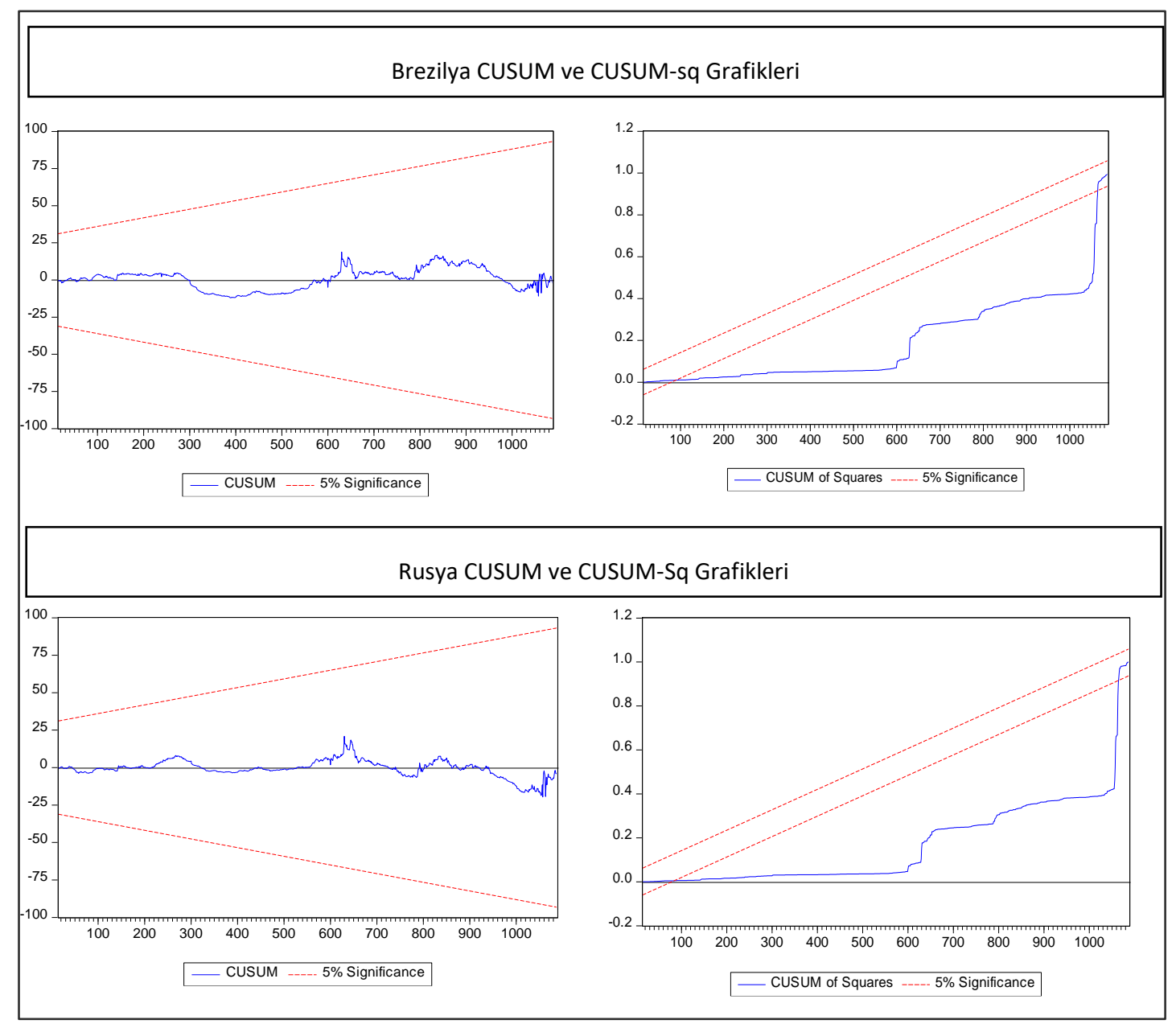

Şekil 2. CUSUM ve CUSUM-Sq Grafikleri

\subsection{Nedensellik Testlerinin Sonuçlarn}

Türkiye'nin CDS primleri ile BRICS ülkeleri arasında uzun dönemli ilişkinin olmaması ya da istikrarsız olması yönündeki bulgulardan sonra kısa dönemli etkileşimin değerlendirilmesine geçilmiştir. Kısa dönem ilişkilerin test edilmesinde Toda-Yamomoto (1995) Nedensellik Testinden faydalanılmıştır. Her bir model için uygun gecikme uzunluğuna, bilgi kriterlerinden ve otokorelasyon testlerinden yararlanılarak karar verilmiştir. Sonuçlar Tablo 4'te görülmektedir.

Tablo 4. Gecikme Uzunlukları ve Otokorelasyon Testi

\begin{tabular}{lccccc}
\hline & LR & FPE & AIC & SC & HQ \\
\hline \hline TUR-BRA Gecikme & 41 & 32 & 32 & 7 & 16 \\
Otokorelasyon LM & 0.833 & 4.711 & 4.711 & 31.697 & 15.803 \\
& $(0.934)$ & $(0.318)$ & $(0.318)$ & $(0.000)$ & $(0.003)$ \\
\hline TUR-RUS Gecikme & 41 & 31 & 31 & 15 & 24 \\
Otokorelasyon LM & 1.505 & 6.339 & 6.339 & 2.089 & 6.271 \\
& $(0.826)$ & $(0.175)$ & $(0.175)$ & $(0.719)$ & $(0.180)$ \\
\hline TUR-IND Gecikme & 31 & 2 & 2 & 2 & 2 \\
Otokorelasyon LM & 3.669 & 2.279 & 2.279 & 2.279 & 2.279 \\
& $(0.453)$ & $(0.685)$ & $(0.685)$ & $(0.685)$ & $(0.685)$ \\
\hline TUR-CHN & 31 & 28 & 28 & 18 & 18 \\
Otokorelasyon LM & 0.993 & 6.110 & 6.110 & 8.898 & 8.898 \\
& $(0.911)$ & $(0.191)$ & $(0.191)$ & $(0.064)$ & $(0.064)$ \\
\hline TUR-SA & 31 & 28 & 28 & 13 & 16 \\
Otokorelasyon LM & 2.797 & 3.279 & 3.279 & 49.473 & 8.343 \\
& $(0.592)$ & $(0.512)$ & $(0.512)$ & $(0.000)$ & $(0.080)$ \\
\hline
\end{tabular}


Tablo 4'te tüm ülke çiftleri için LR, FPE, AIC, SC ve HQ bilgi kriterlerine göre belirlenen en uygun gecikme uzunluklarına ve otokorelasyon sınaması için LM test istatistikleri ile parantez içinde olasılık değerlerine yer verilmiştir. Gecikme uzunluğunun tespitinde AIC dikkate alınmış, ancak diğer kriterlerin belirlediği otokorelasyonsuz en düşük gecikme uzunluğu ile de test yapılmıştır.

Türkiye ve diğer ülke CDS primleri ile çifter olarak gerçekleştirilen nedensellik analizinin sonuçlarına Tablo 5 'te yer verilmiştir.

Tablo 5. Toda-Yamamoto Nedensellik İlişkileri

\begin{tabular}{lllllllll}
\hline Bağımlı & Türkiye & Türkiye & Türkiye & Türkiye & Türkiye & Türkiye & Türkiye & Türkiye \\
Bağımsız & Brezilya & Rusya & Rusya & Hindistan & Çin & Çin & G. Afrika & G. Afrika \\
Gecikme & 32 & 31 & 15 & 2 & 28 & 18 & 28 & 16 \\
Ki-Kare & 338.221 & 217.127 & 127.804 & 5.9895 & 219.058 & 179.751 & 424.406 & 331.783 \\
Olasılık & 0.000 & 0.000 & 0.000 & 0.050 & 0.000 & 0.000 & 0.000 & 0.000 \\
\hline \hline Bağımlı & Brezilya & Rusya & Rusya & Hindistan & Çin & Çin & G. Afrika & G. Afrika \\
Bağımsız & Türkiye & Türkiye & Türkiye & Türkiye & Türkiye & Türkiye & Türkiye & Türkiye \\
Gecikme & 32 & 31 & 15 & 2 & 28 & 18 & 28 & 16 \\
Ki-Kare & 81.8516 & 64.422 & 26.384 & 0.2440 & 135.483 & 104.521 & 91.735 & 64.517 \\
Olasılık & 0.000 & 0.000 & 0.003 & 0.885 & 0.000 & 0.000 & 0.000 & 0.000 \\
\hline
\end{tabular}

Toda-Yamamoto yönteminden elde edilen sonuçlar, Türkiye ile Brezilya, Rusya, Çin ve G. Afrika'nın CDS primleri arasında çift yönlü güçlü bir nedensellik ilişkisi bulunduğunu ortaya koymaktadır. Türkiye'den Hindistan'a doğru bir nedensellik bulunamazken, Hindistan'dan Türkiye'ye nedensellik ilişkisinin olmadığ yönündeki H0 hipotezi reddedilebilmektedir. ARDL çözümünden elde edilen sonuçlarda uzun dönemde Brezilya ve Rusya ile ilişkide istikrarsızlıklar bulunduğu, Çin, Hindistan ve Güney Afrika ile ilişki bulunmadığ 1 tespit edilmekle birlikte, kısa dönemde bu ülkelerin risklerini etkileyen ortak faktörlerin bulunduğu anlaşılmaktadır. Nedensellik ilişkisinin varlığı, ele alınan ülkeler için ülke risklerinde kısa dönemli geçişkenlikler olduğunu düşündürmektedir. Benzer bir çalı̧̧mada Reyhan ve Gazel (2020) gelişmekte olan ülkelerin CDS primleri arasında anlamlı Granger nedensellik ilişkileri gözlemlemişlerdir. Yazarlar diğer ülkelerden Türkiye'ye bir nedensellik tespit edememişken, Türkiye'den G. Afrika ve Rusya'ya nedensellik ilişkisi bulmuşlardır. Milobedzki ve Nowak (2019) ise Çek Cumhuriyeti, Polonya ve Macaristan'ın CDS primlerinin birbirleri ile ve Almanya ile etkileşimlerini inceledikleri çalışmalarında uzun dönem ilişkinin oldukça nadir gözlendiğini fakat kısa dönem nedenselliklere daha sık rastlandığını ortaya koymuşlardır.

\section{SONUÇ}

Elde edilen bulgular, Türkiye'nin CDS primlerinin BRICS ülkeleri ile etkileşim halinde olduğunu ortaya koymaktadır. Uzun dönemde Brezilya ve Rusya ile eş-hareketlilik görülürken, kısa dönemde bu iki ülkeye ilave olarak Çin ve Güney Afrika ile çift yönlü, Hindistan ile ise tek yönlü nedensellik ilişkileri tespit edilmiştir. Ne var ki uzun dönemde Türkiye'nin CDS primlerinin diğer ülkelerden ayrıştığı ve ilişkinin istikrarının bozulduğu dikkat çekmektedir. Bu bağlamda Türkiye'nin ülke riski ile BRICS ülkeleri arasında bir geçişkenlik bulunmakla birlikte, Türkiye'nin ülke riskinin kendine özgü bir takım faktörlerden daha fazla etkilendiği söylenebilir. Özellikle araştırmanın gerçekleştiği dönem dikkate alındığında gerek 15 Temmuz 2016 tarihindeki darbe girişiminin, gerekse 2018 yılında yaşanan döviz kuru şokunun ve 2019 yılında Türkiye-ABD arasındaki S 400 gerginliğinin, küresel faktörlerin Türkiye'nin CDS primleri üzerindeki etkisini baskılayan ve diğer ülkeler ile uzun dönemli etkileşimini bozan başlıca gelişmelerden olduğu düşünülmektedir.

Bu bulgular doğrultusunda bu çalışmada incelenen dönem itibarıyla Türkiye'nin ülke riskinin diğer ülkelerden farklı dinamikler tarafından belirlendiği ancak bir ülkede ortaya çıkan bir şokun, gelişmekte olan ülkeleri birbirine bağlayan mekanizmalar yoluyla diğer ülkelerde de kısa dönemli tepkilere neden olduğu gösterilmiştir. Ulaşılan literatür ülke risklerinde meydana gelen değişimlerin, kendine özgü faktörlerden ziyade küresel risk faktörlerinden etkilenmesi durumunda ülke CDS primlerinin eş hareketlilik sergileyeceğine ve herhangi bir çeşitlendirmenin faydasız olacağına dair bulgular ortaya koymaktadır. Bu çalışmada da farklı kıtalarda bulunmakla birlikte ortak bir takım özelliklere sahip gelişmekte olan ülkelerin yatırımcılarına ampirik bir bakış açısı sunulmaktadır. Ülke riskleri arasındaki geçişkenliğin ve etkileşimin 
tespiti, uluslararası yatırımcıların yatırım kararları üzerine etkili olabilir. Sonuçlar CDS primlerinin uzun dönemli eş hareketliliğini kesin olarak gösteremese de kısa dönemde yakın etkileşimler olduğu belirlenmiştir. Ancak çalışmanın sonuçları yorumlanırken, bulguların incelenen döneme göre farklılık gösterebileceğinin göz önünde bulundurulması gerekmektedir. Ayrıca CDS'lerin spekülatif bir yatırım aracı olarak da rağbet görmesi küresel risk faktörlerinin etkisini azaltarak eş hareketlilikleri ortadan kaldırabilmektedir. Uzun dönem ilişkisinin istikrarını bozan mekanizmaların tespit edilmesi ya da nedensellik ilişkilerini etkileyen faktörlerin daha detaylı araştırılması literatüre katkı sağlayacaktır.

\section{KAYNAKÇA}

Abid, F., \& Naifar, N. (2006). Credit Default Swap Rates and Equity Volatility: A Nonlinear Relationship. The Journal of Risk Finance, 7(4), 348 - 371.

Afonso, A., Furceri, D., \& Gomes, P. (2012). Sovereign Credit Ratings and Financial Markets Linkages: Application to European Data. Journal of International Money and Finance, 31(3), 606-638.

Afsal, M.Ş., Doğan, İ., Örün, E. \& Aydın, B. (2018). Enflasyonun Stokastik Belirleyicileri: Türkiye Ekonomisi için bir NARDL Yaklaşımı. Journal of Life Economics, 5(4), 57-74.

Akel, V. \& Gazel, S. (2014). Döviz Kurları ile BIST Sınai Endeksi Arasındaki Eşbütünleşme İlişkisi: Bir ARDL Sınır Testi Yaklaşımı. Erciyes Üniversitesi İIBF Dergisi, Sayı:44, Temmuz-Aralık 2014, $23-41$.

Akkaş, M.E. \& Sayılgan, G. (2015). Housing Prices and Mortgage Interest Rate: Toda-Yamamoto Causality Test. Journal of Economics, Finance and Accounting, 2(4), 572-583.

Aktuğ, R.E. (2015). Empirical Dynamics of Emerging Financial Markets During the Global Mortgage Crisis. Borsa İstanbul Review, 15(1), 17-36.

Amato, J.D. (2005) Risk Aversion and Risk Premia in the CDS Market. BIS Quarterly Review, December, 55-68.

Anderson, M. (2017). What Drives the Commonality Between Credit Default Swap Spread Changes?. Journal of Financial and Quantitative Analysis, 52(1), 243-275.

Anton, M., Mayordomo, S. \& Rodriguez-Moreno, M. (2018). Dealing with Dealers: Sovereign CDS Comovement. Journal of Banking and Finance, 90, 96-112.

Apergis, N., Lau ,M.C.K. \& Yarovaya , L. (2016). Media Sentiment and CDS Spread Spillovers: Evidence form the GIIPS Countries. International Review of Financial Analysis, 47, 50-59.

Arbia, G., Bramante, R., Facchinetti, S. \& D. Zappa (2018). Modeling Inter-country Spatial Financial Interactions with Graphical Lasso: an Application to Sovereign co-Risk Evaluation. Regional Science and Urban Economics, 70, 72-79.

Asgharian, H., Liu, L. \& Larsson, M. (2018). Corss-border Asset Holdings and Comovements in Sovereign Bond Markets. Journal of International Money and Finance, 86, 189-206.

Aydın, G. K., Hazar, A. \& Çütcü, İ. (2016). Kredi Temerrüt Takası ile Menkul Kıymet Borsaları Arasındaki İlişki: Gelişmiş ve Gelişmekte Olan Ülke Uygulamaları. Journal of Turkish Social Sciences Research, 1(2), $1-20$.

Balı, S., \& Yılmaz Z. (2012). Kredi Temerrüt Takası Marjları ile İMKB 100 Endeksi Arasındaki İlişki. 16. Finans Sempozyumu, 10-13 Ekim, Erzurum, 83-104.

Bouri, E., Boyrie, M.E., \& Pavlova, I. (2017). Volatility Transmission from Commodity Markets to Sovereign CDS Spreads in Emerging and Frontier Countries. International Review of Financial Analysis, 49, 155-165.

Bozkurt, İ. (2015). Finansal İstikrar ile CDS Primleri Arasındaki İlişkinin Bulanık Regresyon Analizi ile Tespiti: Türkiye Örneği. Gümüşhane Üniversitesi Sosyal Bilimler Elektronik Dergisi, 6(13), 64-80.

Broto, C \& Quiros, G. Perez (2015). Disantangling Contagion Among Sovereign CDS Spreads During the European Debt Crisis. Journal of Empirical Finance, 32, 165-179.

Buchholz, M. \& Tonzer, L. (2016). Sovereign Credit Risk co-movements in Eurozone: Simple Interdependence or Contagion?. International Finance, 19(3), 246-268. 
G. Göçmen Yağcılar - Z. Arslan 12/3 (2020) 2461-2475

Caceres, C., Guzzo, V. \& Segoviano, M. (2010). Sovereign Spreads: Global Risk Aversion, Contagion of Fundamentals." IMF Working Papers, WP/10/120.

Calani, M. (2012). Spillovers of the Credit Default Swap Market. Working Papers Central Bank of Chile, 678, Central Bank of Chile.

Chan-Lau, J.A. \& Kim, Y.S. (2004) Eequity Prices, Credit Default Swap and Bond Spreads in Emerging Markets. IMF Working Papers, WP/04/27.

Claeys, P. \& Vasicek, B. (2014). Measuring Bilateral Spillover and Testing Contagion on Sovereign Bond Markets in Europe. Journal of Banking and Finance, 46, 151-165.

Consiglio, A., Lotfi, S. \& Zenios, S.A. (2018). Portfolio Diversification in the Sovereign Credit Swap Markets. Annals of Operations Research, 266, 5-33.

Cossin, D., Hricko, T., Aunon- Nerin, D., \& Huang, Z. (2002). Exploring for the Determinants of Credit Risk in Credit Default Swap Transaction Data: is Fixed-Income Markets'Information Sufficient to Evaluate Credit Risk?. FAME Research Paper: 65.

Çam, A.V. (2010). Ülke Riskinin Firma Değeri Üzerine Etkisi: İMKB’ye Kayıtlı Firmalar Üzerine bir Uygulama. Doktora Tezi, Selçuk Üniversitesi, Sosyal Bilimler Enstitüsü İşletme Anabilim Dalı, Konya.

Çepni, O., Küçüksaraç, D. \& Yılmaz, M.H. (2017). The Sensitivity of CDS Premium to the Global Risk Factor: Evidence from Emerging Markets. Central Bank of Türkiye, Research Notes in Economics, 2017-04.

Erdil, T. B. (2008), “Finansal Türevler ve Kredi Temerrüt Swaplarının Teori ve Uygulamaları", Doktora Tezi, Kadir Has Üniversitesi, Sosyal Bilimler Enstitüsü, Finans\&Bankacılık, İstanbul.

Evci, S. (2020). Kredi Temerrüt Swapları ile Borsa İstanbul Arasındaki Eşbütünleşme İlişkisinin Analizi. Gaziantep Üniversitesi İktisadi ve İdari Bilimler Fakültesi Dergisi, 2(1), 100-117.

Eyssell, T., Fung, H-G., \& Zhang, G. (2013). Determinants and Price Discovery of China Sovereign Credit Default Swaps. China Economic Review, 24, 1-15.

Fabozzi, F.J., Cheng, X., \& Chen, R-R. (2007). Exploring the Components of Credit Risk in Credit Default Swaps. Finance Research Letters, 4(1), 10-18.

Fabozzi, F.J., Giacometti, R. \& Tsuchida, N. (2016). Factor Decomposition of the Eurozone Sovereign CDS Spreads. Journal of International Money and Finance, 65, 1-23.

Fender, I., Hayo, B. \& Neuenkirch, M. (2012). Daily Pricing of Emerging Market Sovereign CDS Before and During the Global Financial Crisis. Journal of Banking \& Finance, 36, 2786-2794.

Finnerty, J. D., Miller C. D., \& Chen R-R. (2013). The Impact of Credit Rating Announcements on Credit Default Swap Spreads. Journal of Banking \& Finance, 37 (6), 2011-2030.

Fontana A. \& Scheicher, M. (2010). An Analysis of Euro Area Sovereign CDS and Their Relation with Government Bonds. ECB Working Paper Series, No. 1271.

Fung, H-G., Sierra, G. E., Yau, J., \& Zhang, G. (2008). Are the U.S. Stock Market and Credit Default Swap Market Related? Evidence from the CDX Indices. Journal of Alternative Investments, July 7,1-46.

Gök, İ.Y. \& Arslan, Z. (2019). Kredi Temerrüt Swap Spreadleri ve Kredi Derecelendirme Duyuruları Arasındaki İlişki: Gelişmekte Olan Ülkeler Kapsamında bir Araştırma. Uluslararası İktisadi ve İdari Incelemeler Dergisi, 24, 301-314.

Greatrex, C.A. (2009). Credit Default Swap Market Determinants. The Journal of Fixed Income, 18 (3),18-32.

Gün, M., Kutlu, M., \& Karamustafa, O. (2016). Gezi Parkı Olaylarının Türkiye Kredi Temerrüt Swapları (CDS) Üzerine Etkisi. İşletme Araştırmaları Dergisi, 8(1), 556-575.

Hancı, G. (2014). Kredi Temerrüt Takasları ve BİST-100 Arasındaki İlişkinin İncelenmesi. Maliye Finans Yazıları, 28(102), 9-22. 
Hassan, K., Hoque, A. \& Gasbarro ,D. (2017). Sovereign Default Risk Linkage: Implication for Portfolio Diversification. Pasific-Basin Finance Journal, 41, 1-16.

Hassan, M.K., Isiugo, U. \& Zhang, Z. (2016). Characterizing Sovereing Credit Risk Interdependencies: Evidence from the Credit Default Swap Market. SSRN Electronic Journal, http://dx.doi.org/10.2139/ssrn.2745033.

Hassan, M.K., Maroney, N.C., El- Sady, H.M., \& Telfah, A. (2003). Country Risk and Stock Market Volatility, Predictability and Diversification in the Middle East and Africa. Economic Systems, 27(1), 63-82.

Hausmann, R. (2000). Chapter 4-Latin America: No Fireworks, No Crisis?. (ed.) Bisignano, J.R., Hunter, W. and Kaufman, G.G., Global Financial Crises: Lessons from Recent Events, Spinger Science+Business Media, LLC, pp. 27-48.

Heinz, F. F., \& Sun, Y. (2014), “Sovereign CDS Spreads in Europe: The Role of Global Risk Aversion, Economic Fundamentals, Liquidity, and Spillovers", IMF Working Papers: W/14/17.

Ho, S.H. (2016). Long and Short-runs Determinants of the Sovereign CDS Spread in Emerging Countries. Research in International Business and Finance, 36, 579-590.

Hull, J., Predescu, M., \& White, A. (2004). The Relationship Between Credit Default Swap Spreads, Bond Yields, And Credit Rating Announcements. Journal of Banking \& Finance, 28 (11), 2789-2811.

Ismailescu, I., \& Kazemi, H. (2010). The Reaction of Emerging Market Credit Default Swap Spreads to Sovereign Credit Rating Changes. Journal of Banking \& Finance, 34(12), 2861-2873.

Karg1, B. (2014). Credit Default Swap (CDS) Spreads: The Analysis of Time Series for the Integration with the Interest Rates and the Growth in Turkish Economy. Montenegrin Journal of Economics, 10(1), 59-66.

Kılcı, E.N. (2017). CDS Primleri ile Ülke Kredi Riski Arasındaki İlişkinin Değerlendirilmesi; Türkiye Örneği. Maliye Finans Yazıları, 108, 71-86.

Kocsis, Z. \& Monostori, Z. (2016). The Role of County-Specific Fundamentals in Sovereign CDS Spreads: Eastern European Experiences. Emerging Markets Review, 27, 140-168.

Kuepper, J. (2019, December 11). "Investig in Newly Industrilized Countries", https://www.thebalance.com/what-are-newly-industrialized-countries-nics-1978978, Erişim: 14.05.2020.

Kurt Cihangir, Ç. (2020). Volatılity Spillover Effects From Global and National Variables to Sovereign CDS Spreads: Evidence From Turkey. SDÜ Vizyoner Dergisi, 11(26), 45-61.

Lehnert, T., \& Neske, F. (2006). On the Relationship Between Credit Rating Announcements and Credit Default Swap Spreads for European Reference Entities. Journal of Credit Risk, 2(2), 83-90.

Longstaff, F. A., Pan, J., Pedersen, L., \& Singleton, K. (2011). How Sovereign is Sovereign Credit Risk. American Economic Journal:Macroeconomics, 3(2), 75-103.

Longstaff, F.A., Pedersen, L.H. \& Singelton, K.J. (2007). How Sovereign is Sovereign Credit Risk?. NBER Working Paper, No. 13658.

Micu, M., Remolona, E., Woolridge, P.D. (2004). The Price Impact of Rating Announcements: Evidence from the Credit Default Swap Market. BIS Quarterly Review, June, 55-65.

Milobedzki, P. \& Nowak, S. (2019). Chapter 20: the Co-movement of the Czech Republic, Hungary and Poland Sovereign Credit Default Swap Spreads. Eds. W. Tarczynski \& K. Nermend, in Effective Investments on Capital Markets (285-300), CMEI 2018, Springer.

Norden, L., \& Weber, M. (2004). Informational Efficiency of Credit Default Swap and Stock Markets: the Impact of Credit Rating Announcements. Journal of Banking \& Finance, 28(11): 2813-2843.

Palladini, G. \& Portes, R. (2011). Sovereign CDS and Bond Pricing Dynamics in the Euro-Area. NBER Working Papers No. 17586. 
G. Göçmen Yağcılar - Z. Arslan 12/3 (2020) 2461-2475

Pan, J. \& Singleton, K.J. (2008). Default and Recovery Implicit in the Term Structure of Sovereign CDS Spreads. The Journal of Finance, 63(5), 2345-2384.

Papaioannou, G. (2011). Economic and Market Factors Versus Credit Rating Announcements, on Credit Default Swap Spreads. International Journal of Economics and Finance, 3(5), 42-48.

Pesaran, M.H., Shin, Y. \& Smith, R. (1999). Pooled Mean Group Estimation of Dynamic Heterogenous Panels. Journal of the American Statistical Association, 94(446), 621-634.

Pesaran, M.H., Shin, Y. \& Smith, R. (2001). Bounds Testing Approachs to the Analysis of the Level Relationship. Journal of Applied Econometrics, 16, 289-326.

Rajan, M. \& Friedman, J. (1997). An Examination of the Impact of Country Risk on the International Porfolio Selection Decision. Global Finance Journal, 8(1), 55-70.

Reyhan, Y. \& Gazel, S. (2020). CDS Primleri Arasındaki Etkileşim: Gelişmekte Olan Ülkeler Üzerine Bir İnceleme. Finans, Politik \& Ekonomik Yorumlar, 651 (Mart 2020), 181-215.

Shin, Y., Yu, B. \& Greenwood-Nimmo, N. (2014). Modelling Asymmetric Cointegration and Dynamic Multipliers in a Nonlinear ARDL Framework. R. Sickels \& W. Horrace (eds.). Festschriftin Honor of Peter Schmidt: Econometric Methods and Applications, New York: Springer, 281-314.

Shino, J. \& Takahashi, K. (2010). Sovereign Credit Default Swaps: Market Developments and Factors behind Price Changes. Bank of Japan Review, 2010-E-2.

Stolbov, M. (2014). The Causal Linkages Between Sovereign CDS Prices for the BRICS and Major European Economies. Economics, Vol. 8, 2014-26.

Tang, D.Y. \& Yan, H. (2006). Liquidity, Liquidity Spillover and Credit Default Swap Spreads. Erişim adresi: https://www.fdic.gov/bank/analytical/cfr/2006/apr/tang-yan.pdf, erişim tarihi: 02.06.2020.

Toda, H. Y. \& Yamamoto. T. (1995). Statistical Inferences In Vector Autoregressions With Possibly Integrated Processes. Journal of Econometrics, 66(1-2), 225-250.

Turan, T. \& Karakaş, M. (2018). Devlet Harcamaları ve Gelirler Arasındaki İlişki: Doğrusal Olmayan Sınır Testi Yaklaşımı (NARDL). Sosyoekonomi, 26(36), 33-48.

Tükenmez, N.M., \& Kutay, N. (2016). Ülke Riskinin Hisse Senetleri Getirileri Üzerine Etkisi: Türkiye ve Arjantin Piyasaları için bir Karşılaştırma. Atatürk Üniversitesi Sosyal Bilimler Enstitüsü Dergisi, 20 (2), 631645.

Varlık S. \& Varlık, N. (2017). Türkiye'nin CDS Priminin Oynaklığı. Finans, Politik \& Ekonomik Yorumlar, 54(632), 9-17.

Wang, P \& Moore, T. (2012). The Integration of the Credit Swap Markets during the US Subprime Crisis: Dynamic Correlation Analysis. International Financial Markets, Institutions and Money, 22, 1-15.

Yapraklı, S., \& Güngör, B. (2007). Ülke Riskinin Hisse Senedi Fiyatlarına Etkisi: İMKB 100 Endeksi Üzerine bir Araştırma. Ankara Üniversitesi SBF Dergisi, 62- 2, 200-218.

Yüksel, A. \& Yüksel, A. (2017). Avrupa Borç Krizi Döneminde Global Risk Faktörleri ve Ülke Kredi Temerrüt Takası Primi İlişkisi: 19 Ülke Örneği. Akdeniz İ.İ.B.F. Dergisi, 36, 1-18.

Zhu, H. (2004). An Empirical Comparison of Credit Spreads Between the Bond Market and the Credit Default Swap Market. BIS Working Paper:160.

Zinna, G. (2013). Sovereign Default Risk Premia: Evidence from the Default Swap Market. Journal of Empirical Finance, 21, 15-35. 